\title{
'DESPERATELY MORTAL': EXCLUSION IN SHAKESPEARE'S LEGAL PLAYS
}

\author{
JOHN R MORSs
}

[Shakespeare's most explicitly 'legal' plays are The Merchant of Venice and Measure for Measure. Both examine the interaction between human desire on one hand and the law on the other. In both plays laws cuts through the social hierarchies, either neutralising or exaggerating them. Key characters find their exclusion nullified by the law, and then discover inclusion is far worse than exclusion.].

\section{Phenomenological INTROdUCtION: 'EXCLUSION By INCLUSION'}

In the course of articulating a phenomenological account of legal discourse, William Conklin examines what he calls the 'enclos[ing]' of the experiences of a plaintiff by the discourse of judges, in an alleged discrimination case. ${ }^{1}$ The case concerned a Ms Bhadauria who despite making many applications for jobs for which she was well qualified did not get offered any interviews. Conklin claims that "the harm of denying Ms Bhadauria a job interview only worsened once she was immersed into the legal discourse." Legal professionals, Conklin reports, used legal terminology and short forms of case names such that "the knowers' language" became "more obfuscating". Thus "[a] new type of suffering displaced Ms Bhadauria's experience of receiving her rejection letters."

\footnotetext{
* Associate Head, Deakin University Law School, Burwood, Victoria. I would like to express my thanks to Michael Meehan for encouraging my ventures. .

${ }^{1}$ William Conklin, The Phenomenology of Modern Legal Discourse (1998). It should be stressed that Conklin also problematises the notion of 'case' (at 42) as another trope of exclusion: "Mrs Bhadauria was just that - a case" (at 43); similarly 'plaintiff.'
} 
As a consequence of their "assimilation of Ms Bhadauria's felt experience of pain into the secondary authoritative discourse," Conklin notes, the judges occluded that experience and did not adequately (in fact did not even remotely) recognise it. Ms Bhadauria's experience was "excluded" by being "included" or so Conklin's sub-heading (quoted in my own, above) asserts. Thus:

When a knower claims to 'know' the facts of a non-knower, the knower intuitively takes the non-knower to be a living subject. But the knower does so by analogizing about the non-knower from experiences which the knower has had in the past. The non-knower is analogized inside the knower's constituting consciousness. ${ }^{2}$

Conklin's phenomenological approach seeks to apply a Gadamerian perspective to the processes by which the law responds to individual needs. Thus he emphasises the lack of common ground between the judicial system and the so-called 'plaintiff,' that is to say, the absence of shared 'forestructures of understanding' or in Gadamer's term of art, of 'prejudice.' The appropriate remediation according to Conklin is to modify Gadamer with a little Bakhtin. Thus:

The justice of a dialogic relation dwells in the murmur of multiple embodied meanings... The knower must recognize the language of a nonknower in order to carry on a dialogue... Dialogue helps to recover the saying of what was said.

Justice for Conklin "lies in the heterology of voices embedded in the silent intertext between dialogic partners." "In this condition there is no inclusion and hence no exclusion, only a reaching-out to an unknown shared arena. Yet even here there is difference: "the justice of the language of the non-knower $\ldots$ is concrete and context-specific" in contrast to the "idealism of the justice of the secondary genre [of legal discourse]." The particular, contrastive descriptions Conklin gives of these two modes is familiar but this should not distract us from his general point, that the shared space of justice is not homogeneous. Thus when we see that exclusion is caused by inclusion, and that we must therefore strive to exclude inclusion, we are driven to examine the contestation of discourses: a dramatic space, a space of performance.

\footnotetext{
${ }^{2} I d$. at 205 , emphases in original.

${ }^{3} I d$. at 240-1, emphases in original.

${ }^{4} I d$. at 244 .

${ }^{5}$ Loc cit.
} 
Moreover as Conklin notes, even if one accepts such an analysis as representing what is not merely conceivable but also desirable, the question remains "How does one institutionalize such a dialogic relationship?"6 The same question arises from a Levinasian perspective: ${ }^{7}$ how can I prioritise the face of the other in such a way that this absolute inclusion does not occlude the faceless ones? This is a question about the organisation of justice - its social structuration - that is to say, 'the law.' It is a question about the scene of law. Scene One is set in Venice; Scene Two in Vienna.

\section{EXCLUSION IN THE BARD}

The two plays selected for principle discussion here are the two plays of Shakespeare identified by commentators ${ }^{8}$ as the most explicitly 'legal' in subject-matter. The Merchant of Venice and Measure for Measure both deal with the application of law and with conflicts between different ways of apperceiving and implementing law. Both plays expressly contextualise law within the dynamics of human desire and of social institutions - Critical Legal Studies avant la lettre as it were.

Both examine the aspiration for principles of justice that might transcend the everyday world of commerce and of lust, and both cast this aspiration in an ironic light. The rhetorical aspects of law are spotlighted in both plays, with the highest flights of poetic fancy being reserved for the representation of advocacy ("the quality of mercy is not strained...") rather than for soliloquy. Law throughout these plays is performative, a matter of 'how to do things with words,' a contested form of social practice that cross-cuts the more obvious hierarchies of power like an interfering wave, sometimes neutralising them and sometimes amplifying them to horrifying extents. Law is a supplement to normal human activity.

Neither play is easy to categorise in terms of the traditional troika of Shakespearean genres (comedy, tragedy, history), both requiring to be termed

${ }^{6} I d$. at 245; see Tony Waters, Bureaucratizing the Good Samaritan (2000).

${ }^{7}$ Conklin, supra note 2, at 45; also see John R Morss, Saving Human Rights from Its Friends: The imaginary ethics of Costas Douzinas, 27 Melbourne U. L. Rev. 889 (2003).

${ }^{8}$ Daniel Kornstein, Kill All the Lawyers: Shakespeare's Legal Appeal 63 (1994); the selection coincides with the present author's own acting experience in The Merchant of Venice Dir. Donald Hope-Evans, with Lyndon Hood as Shylock, 2000; and in Measure for Measure Dir. Lyndon Hood with Andrew Patterson as Angelo, 2001; both at the Globe Theatre, Dunedin, New Zealand. 
'comedies' because of their (if incomplete) resolutions while both seem to resist such categorisation. Measure for Measure has been long classified as a 'problem play' and as the only play in common between numerous critics' versions of this useful category ${ }^{9}$ it perhaps deserves to be called the problem play. In travelling the road from The Merchant to Measure for Measure Shakespeare may have progressed from answer to problem. Both plays centre on the actions of a villain ${ }^{10}$ who attempts but fails to harness the law as he finds it to be, for his personal agenda (as plaintiff in Shylock's case, as executive in the case of Measure for Measure's Angelo). Neither Shylock nor Angelo is villainous enough to see himself and to perform himself as above the law or (which is the same thing) as a law-maker, as do the grand villains like Richard III and King Lear's Edmund. Such grand villains treat law with disdain, but this form of burlesque is not available to the bawds of Vienna or to the only slightly less grubby merchant class of Venice.

Indeed the law-makers in both plays (dukes both) are minor characters in the drama. Both Shylock and Angelo are creatures of the law, extruded by it in its mock-Venetian and mock-Viennese manifestations, respectively. Neither seeks to change the law, merely to serve it as it serves them. And both are ultimately the fools of the law, destroyed by it in the form of advocacy (The Merchant) or in the form of legislation (Measure for Measure). Both plays end with the "conversion of the villain." In a variety of ways both Shylock and Angelo thus find themselves at last included in the law and find that this is far worse than exclusion ever was. In doing so, they illustrate for us some of the ways in which law works, and some characteristics of its peculiar mixture of exclusions and inclusions. Thus it seems wide of the mark to claim that "equity jurisprudence is painted ... in rosy hues" in these two plays, as claimed by Posner. ${ }^{12}$ The role of equity-like discretion in The

9 Among six lists, All's Well That Ends Well and Troilus and Cressida come joint second with five mentions each; other titles include Hamlet with two nominations: see William Lawrence, Shakespeare's Problem Comedies (1969); Ernest Schanzer, The Problem Plays of Shakespeare (1963); Vivian Thomas, The Moral Universe of Shakespeare's Problem Plays (1987); E. M. W. Tillyard, Shakespeare's Problem Plays (1965); Peter Ure, The Problem Plays (1961) 7 (Boas' and Ure's lists). The Merchant of Venice appears in none of these lists; it is however identified as a problem play by W. H. Auden, Brothers and Others (from The Dyer's Hand [1963]) in Shakespeare: The Merchant of Venice: A Casebook 224-240, 229 (John Wilders ed., 1969).

${ }^{10}$ While Shylock is no Richard III, attempts to read him as a sympathetic figure seem strained: Harold Bloom, Shakespeare: The Invention of the Human 171 (1999).

${ }^{11}$ The phrase is used of Measure for Measure by Lawrence, supra note 10, at 114.

${ }^{12}$ Richard Posner, Law and Literature 143 (rev ed, 1998). 
Merchant is contaminated by the treatment of Shylock by the court, and it is hard to find anything even resembling equity in Measure for Measure. As Thomas comments in relation to the latter, "Shakespeare is not making some glib point about striking a careful balance between rigour and compassion."13

\section{THE MERCHANT OF VENICE}

The Merchant of Venice, probably dated circa $1596-7^{14}$ is a play about exclusion in several ways. While Shylock's exclusion is patent, he is at the end included (forcibly) into Christian society when his life is spared only on the condition of conversion. In Belmont, the "richly left" Portia manipulates her deceased father's will, with its riddle of the three caskets, so as to hitch up with the attractive, irresponsible Bassanio, for no other reasons it appears than that he is attractive and irresponsible, and above all not foreign. Portia peremptorily excludes suitors from other ethnic or national backgrounds in a still crowd-pleasing stand-up routine, a parody of the institutionalised discrimination that characterises Venice.

Later Portia manipulates the Law of Venice in order to save the life of Bassanio's friend, whose predicament is one assumes distracting him and thus preventing them (Portia and Bassanio) from consummating their nuptials; but in terms of Portia's motivation, the extended courtroom scene is a sideshow. Shylock leaves the stage in Act IV Scene i, excluded by the bratpack which takes over the stage for the remaining time. In terms of the structure of the play what is noticeable is the marginal role played by The Merchant himself, Antonio. If it be accepted that play is a comedy, and that the joyful Christian pairings at the end (Portia: Bassanio, Nerissa: Gratiano and Jessica: Lorenzo) are integral to the structure, then Antonio's solitude cannot be explained merely by the absence of a convenient and unattached female character. Antonio starts alone and ends alone. Antonio lends money freely but has no wife; his lending of money represents a kind of celibacy or impotence since no breeding results from the activity. He is an idle but a squeaky wheel. By lending money to his friends (fellow-Christians) without interest, Antonio is repudiating the role of money as currency: denying its 'natural' breeding role in a mercantile state that relies on trade.

\footnotetext{
${ }^{13}$ Thomas, supra note 10 , at 176 .

${ }^{14}$ Bloom, supra note 11, at 172.
} 
Certainly for Auden, Antonio's intense (and to that extent not fully reciprocated) attachment to Bassanio is suggestive. ${ }^{15}$ Such "inordinate affection" is for Auden to be linked with Antonio's willingness to stand surety for his friend, a practice condemned in Shakespeare's time (as Auden demonstrates) by Lord Burghley, Sir Walter Raleigh and Martin Luther. In doing so Antonio, like Shylock, risks everything, whereas Bassanio patently does not even though the third casket's motto stated that "Who chooseth me, must give and hazard all he hath." It is Antonio and Shylock who are excluded from the happy land of Belmont (Antonio by remaining single). ${ }^{16}$ Both have voluntarily adopted courses of action, consistent with their respective natures, that make this inevitable. Neither of them belong with "the Christian husbands" while Bassanio clearly does.

Shylock, against his nature as it were, offers an interest-free loan to Antonio - that is he offers the kind of loan made between Christian friends in Venice. Shylock tempts providence by doing so, and is accordingly punished (by fate). It may be that Shylock is to be seen as punished for seeking to change his nature. The anti-Semitism of the play $^{17}$ (notwithstanding the occasional loopholes provided to the viewer like so many blank cartridges at a firing squad) can hardly be doubted. In lending without interest - even though this is accompanied by the 'merry jest' of Antonio's body-bond - Shylock is thus aping the Christian. His assigned role is to charge interest and to be spurned for charging interest. More generally Shylock has surely been aping the Christian in keeping a Christian as his house-servant (the younger Gobbo) and as it turns out at the end, he has been aping the Christian husbands in symbolising his betrothal vows with a ring (the ring exchanged for a monkey by his runaway daughter). It seems that Shylock's humanity is treated by the unfolding play as a mockery and a joke, his communalities with the gentiles of Venice being stripped away from him one by one. The fact that Shylock is articulate and even witty merely heightens the effect and thereby intensifies the humiliation.

Above all, in The Merchant nobody refuses to play along with the charade. All of Portia's suitors accept her rules. Shylock accepts the rules of the Venice courtroom (he does not reject its jurisdiction, and nor does he wheel in the Jewish lawyers). Antonio accepts the jurisdiction of the court, perhaps because he voluntarily rendered vulnerable his body and perhaps even with a hint of masochism. In its characters' dogged commitment to the narrative

\footnotetext{
${ }^{15}$ Auden, supra note 10 , at 236.

${ }^{16}$ Id. at 239-240.

${ }^{17}$ Bloom, supra note 11 , at 171.
} 
form in which they find themselves - excluding any realisation of alternatives - The Merchant is farce-like. This is the case as well in the more general shallowness of characterisation in the play: the characters' motivation is no more and no less than the objectives the characters pursue when in our sight. What you see is what you get, as in law:

It is not a valid criticism of the trial of a child that "the real child was not revealed" any more than it would be a valid criticism to say in the trial of an adult, "the real adult was not revealed." 18

Law is not about interiors. As a model of the law, The Merchant of Venice is thus spot-on.

\section{MEASURE FOR MEASURE}

As well as being Shakespeare's 'other' law-play, Measure for Measure seems to represent a re-appraisal of law's relationships with human desire as earlier outlined in The Merchant. In the former play the procedure of the law is appropriated by a clever woman in order to save her betrothed from embarrassment. The law of Venice is treated in that play as objective and unchangeable, independent of the wishes and predilections of its subjects. Although Venice's international dealings are mentioned, as requiring the predictability of commerce and hence the honouring of contracts, there is no Venetian Michael Kirby to propose that International Law be called upon to clarify the municipal obscurities. In the latter play however, laws are found to be not only interpreted and implemented by people, but also made by people. This knowledge proves to be not comforting but terrifying.

In Measure for Measure, thought to have been written in approximately $1604,{ }^{19}$ and thus almost definitely later than The Merchant, we are given a bawd's-eye view of law, and the bawd numbers advocates and government officials among his clients. The Duke of Vienna spies on and manipulates his subjects for all the world as in the reality television shows so characteristic of our recent fin de siecle. ${ }^{20}$ He even takes confessions, ${ }^{21}$ disguised as a friar. In

18 John R. Morss, Rosencrantz and Guildenstern are Nevertheless Dead: The hypothetical adolescence of Prince Hamlet and the contested remorselessness of young offenders, 1 University N.E.L.J. 187, 197 (2004).

${ }^{19}$ Bloom, supra note 11 , at 358.

${ }^{20}$ Splendidly satirised by Ben Elton, Dead Famous (2002). 
what one might term the 'pre-credit sequence', the Duke purports to leave his city's governance in the untested hands of his deputy Angelo who immediately proceeds to enforce the Duke's laws, hitherto unobserved 'dead letters. ${ }^{22}$ In particular, the harsh proscription of premarital intercourse is implemented in regard to young Claudio and his betrothed Juliet. Further abusing his power by offering Claudio's sister, the nun-to-be Isabella, the option of saving her brother's life at the cost of her own dishonour, Angelo is tricked into bedding his own abandoned fiancé Mariana and hence committing the exact offence for which he has convicted Claudio.

These machinations are facilitated by the disguised Duke who, finally revealed, proclaims a series of marriages: Juliet and Claudio, Mariana and Angelo, Kate Keepdown (a prostititute) and Lucio (a bawd) and last but not least, a possibly surprised Isabella and himself. Isabella's forced inclusion into the bourgeois marriage stakes by the Duke can be compared with the forced assimilation of Shylock; the effect on her self-image and on her life's trajectory is as traumatic one might think. The matchmaking finale recalls The Merchant. On this occasion the most notable character left out of the couplings is the truculent Barnardine, recalcitrant murderer whose blunt refusal to acquiesce in his own execution offers a sane commentary on the grotesque sophistries of the (disguised) Duke. ${ }^{23}$

Barnardine seems to be at the moral core of the play (if this "masterpiece of nihilism" 24 can be said to have one). Isabella's insistence on justice and chastity have suggested fanaticism ${ }^{25}$ (and perhaps worse, "legalism" ${ }^{26}$ ) whereas Barnardine's disobedience is the acme of level-headedness. Barnardine simply refuses to contribute his body to the punitive whims of the penal system in which he finds himself, in a Vienna that is reminiscent of Shakespeare's London in many respects although "emphatically Roman Catholic". ${ }^{27}$ In this way, rather like Lewis Carroll's Alice refusing to collaborate with the playing cards' tribunal, Barnardine's disavowal - his self-exclusion as one might say - threatens to subvert the whole polity. In remaining uncoupled at the end he recalls Antonio, like him a character

${ }^{21}$ Confessional addresses to camera by inmates of 'Big Brother' facilities are characteristic of the genre: $I d$.

${ }^{22}$ Kornstein, supra note 9, at 46.

${ }^{23}$ Bloom, supra note 11 , at 369 .

${ }^{24} I d$. at 363.

${ }^{25}$ Posner, supra note 13, at 115.

${ }^{26}$ And "puritanism," Schanzer, supra note 10, at 104.

${ }^{27}$ Posner, supra note 23, at 116. 
threatened with death under guise of law and like him also something of a hapless Hitchcockian hero. For both Antonio and Barnardine are drawn into other people's machinations somewhat by happenstance: if Antonio had been on holiday then Bassanio would surely have battened on the next merchant on the Rialto (we even see them disporting), and Barnardine is similarly in the wrong place at the wrong time. The difference between the characters is how they respond to their narrative predicament. Antonio like Kafka's Joseph $\mathrm{K}$, meekly submits; Barnardine raises an expressive finger.

Barnardine commits himself to the circulation of fluids through his body instead of the circulation of his body through the legal system of Vienna. Barnardine's body was in any event wanted only for its head which would have sufficiently resembled that of Claudio for the latter's execution to be simulated; the remainder of his deceased corpse would presumably have been discarded. With Barnardine's refusal to cooperate, another dead head is readily obtained in this farcical adumbration of Blackadder. Men's heads circulate around the Viennese prison, just as presumably women's bodies circulate around the Viennese brothels so that the twin institutions of 'jailhouse and whorehouse ${ }^{28}$ come to represent the metropolis. The bawd Pompey compares the 'merriest' usury (fornication) with the 'worser' usury of money-lending, commenting that the former is prohibited and the latter allowed. ${ }^{29}$ In Measure for Measure therefore exclusion is turned inside-out: just as the Duke absents himself from Vienna, mimicking a banishment, so does Barnardine absent himself from the forensic machine. The law may, he is saying, proceed in his absence.

Law includes the plea in mitigation ${ }^{30}$ - a plea that presupposes the justice of a recent conviction. In a climactic scene, mitigation is sought from Angelo by Isabella on her brother's behalf. ${ }^{31}$ Notably Isabella requires egging-on (by the bawd Lucio) to present her plea, a dynamic that presents a stark contrast with Portia's confident autonomy. ${ }^{32}$ As well as its other dramatic dimensions, this suggests an extra level of mediation and hence of the deliberate deployment of rhetoric by Isabella. Only now, perhaps, as she performs the plea to two

\footnotetext{
${ }^{28}$ Melvin Seiden, Measure for Measure: Casuistry and Artistry 85 (1990).

${ }^{29}$ Thomas, supra note 10, at 186 [qv Measure for Measure III ii 6-8].

${ }^{30}$ Richard Edney, Literary Concepts and the Plea in Mitigation, 9 Deakin L.Rev. 183 (2004)

${ }^{31}$ Ernest Schanzer, Justice and King James in Measure for Measure, in Shakespeare: Measure for Measure: A Selection of Critical Essays 233-241, 234 (C K Stead ed., 1971).

${ }^{32}$ Thomas, supra note 10, at 180.
} 
quite different listeners as well as to herself, is Isabella's powerful intellect fully engaged. For Bate, the role of Isabella is radically ambiguous - its internal inconsistencies to be grasped only through the seventh (and most esoteric) of Empson's seven types of ambiguity. ${ }^{33}$ Of course, Measure for Measure is "singularly apt to provoke its critics to excess." 34 But it is hard not to see Isabella as a Portia stripped of privilege and of self-certainty, venturing way beyond the comfort zone of convention within which the fair maid of Belmont is so careful to remain.

\section{V 'Another language Altogether': THE LAW OF THE STRANGER}

Exclusion became a major literary trope in the twentieth century with the writings of Kafka and Camus among others. Exclusion as a topic was not however an invention of this recent era: the role of 'the stranger' was central to the works of Shakespeare at least as discerned by Leslie Fiedler. ${ }^{35}$ Exclusion and marginalisation are not infrequent themes throughout the plays; Shylock has the Puritan's antipathy to music and hence is brother to the Puritan Malvolio of Twelfth Night. Like Antonio, and like Shylock himself (and indeed like Antonio's namesake in Malvolio's play), Malvolio is left solitary at the end of his play, detached from the celebratory in-crowd.

It is these solitary figures to whom law seems most salient in Shakespeare's world: the well-ordered microcosm characterised by the network of marriage relationship seems not to be in need of it. Rather like the modern family, in which disputes or tensions are seen as matter for therapy before matter for legal intervention, Shakespeare's couple-founded communities are it seems self-regulating as a consequence of having got the basics right. Such selfregulation may conceal mere patriarchy, yet consent and collaboration (as in The Taming of the Shrew) play an essential part in the subservience of young people, women and the labouring classes in Shakespeare's worldview as dramatist: once again, exclusion through inclusion.

Exclusion is perhaps complicit in our contemporary sense of Shakespeare whether or not this was the case in Elizabethan times; Shakespeare as literature is paradigmatically canonical. ${ }^{36}$ There seems no reason to think that

\footnotetext{
33 Jonathan Bate, The Genius of Shakespeare 316 (1997).

${ }^{34}$ Tillyard, supra note 10 , at 118.

${ }^{35}$ Leslie Fiedler, The Stranger in Shakespeare (1974).

${ }^{36}$ Terry Eagleton, Literary Theory: An Introduction 187 (2d ed. 1996).
} 
Shakespeare-and-Law ${ }^{37}$ as a sub-discipline of Law and Literature ${ }^{38}$ amends this exclusionary tendency. Shakespeare's use of legal terminology is much remarked but after all "the Elizabethan dramatist who makes least use of law for metaphor and illustration is the only one who practised as a barrister, John Ford, of the Middle Temple." ${ }^{, 39}$ The Bard was not one of us.

${ }^{37}$ Also see John Sutherland, Henry V, War Criminal?, in Henry V, War Criminal? \& Other Shakespeare Puzzles 108-116 (John Sutherland and Cedric Watts eds., 2000); Ian Ward, Law, Literature and the Child, in Legal Concepts of Childhood 111-126 (Julia Fionda ed., 2001).

${ }^{38}$ Also see John R Morss, Crime Stories: Posnerian pragmatism, Rawlsian pure procedural justice, and the fictional problem, 9 Deakin L.Rev. 643 (2004).

${ }^{39}$ H C Beeching, William Shakespeare, Player Playmaker and Poet: A Reply to $\mathrm{Mr}$ George Greenwood MP 34 (1908). 
